ROCZNIKI NAUK PRAWNYCH

Volume XXVIII, number 2 - 2018

E n g 1 is h ve r s i o n

DOI: http://dx.doi.org/10.18290/rnp.2018.28.2-5en

PIOTR Z. POMIANOWSKI

\title{
FEES PAID IN CIVIL CASES IN THE DUCHY OF WARSAW AND THE KINGDOM OF POLAND (UNTIL 1876)
}

\section{INTRODUCTION}

Issues related to the costs incurred in a civil action have not been given enough attention by the literature on civil proceedings, neither in the past nor in the present. ${ }^{1}$ This situation may stem from the fact that theory-oriented researchers do not see too many issues deserving scientific reflection in this subject area. It is also likely that courts are reluctant to justify their cost-related decisions comprehensively (often just indicating the legal basis for their decisions) and thus do not provide much material for doctrinal considerations. ${ }^{2}$ Similarly, the courts operating in the Duchy of Warsaw and the

Piotr Pomianowski, PhD, is an assistant professor at the Department of History of Political Systems and Polish Law, Institute of History of Law, Faculty of Law and Administration, University of Warszawa; address: ul. Krakowskie Przedmieście 26/28, 00-927 Warszawa, Poland; e-mail: p.pomianowski@gmail.com.

${ }^{1}$ Although there is no shortage of publications of a practical nature on court fees, they are very rarely the subject of scientific monographs. In the commentary to the Code of Civil Procedure edited by Andrzej Zieliński, in the bibliographical list preceding the title on costs of litigation, not a single scientific monograph is mentioned, Kodeks postępowania cywilnego. Komentarz, ed. A. Zieliński (Warszawa: Wydawnictwo C.H. Beck, 2017), 217. A similar list, provided by a commentary edited by Andrzej Marciniak and Kazimierz Piasecki, mentions two dissertations, but they were published a long time ago: T. BuKOwsKI, Rozstrzyganie o kosztach procesu cywilnego (Warszawa: Wydawnictwo Prawnicze, 1971); and K. KorZan, Koszty postepowania cywilnego a nakłady państwa na utrzymanie wymiaru sprawiedliwości (Gdańsk: Wydawnictwo Prawnicze i Ekonomiczne "Lex", 1992), Kodeks postępowania cywilnego. Komentarz, ed. A. Marciniak and K. Piasecki (Warszawa: Wydawnictwo C.H. Beck, 2016), 1:460). The historical-legal bibliography section prepared by Czasopismo Prawno-Historyczne does not mention a single publication on the subject of litigation costs in the nineteenth century.

${ }^{2}$ It should be noted that pursuant to Article 361 of the Act of 17 November 1964 - the Code of Civil Procedure (Journal of Laws of 2016, item 1822, as amended), court decisions (including, obviously, decisions concerning litigation costs) are regulated by provisions on judgements, includ- 
Kingdom of Poland [Congress Poland-Translator's note] usually did not justify their cost decisions, and even if they did, it was done very succinctly. ${ }^{3}$ Nevertheless, for the research on the history of law in the nineteenth century in the Polish lands, this issue is particularly important because it was in the Duchy of Warsaw where a common judiciary system appeared for the first time in this part of Europe. Therefore, it was no longer the social stratification but the ability to bear the burden of court costs (or possibly to exercise the right of poor relief) that determined one's access to courts.

\section{GENERAL LEGAL REGULATIONS}

The basic rules of paying legal costs in the period at hand were governed by the French Code of Civil Procedure of $1806 .{ }^{4}$ In addition, stamp acts that followed were of key importance (discussed below). In addition, numerous

ing Article $328 \S 2$, which prescribes that the justification of a decision should indicate its factual basis, namely: determination of facts which the court considered proved, the evidence used, and the reasons why other evidence was denied credibility and probative value, and an explanation of the legal basis of the judgement with the relevant provisions cited. Nevertheless, it often happens that a mere reference to the legal basis for an adjudication on costs can be considered a sufficient justification (see the decision of the Supreme Court dated October 10, 2013, file ref. no. III CZ 30/13, Legalis no. 877707: "In the case at hand, in which the claimant was wholly unsuccessful in the appeal proceedings, the fact that the Court of the second instance, in its grounds for the decision on costs of appeal proceedings, invoked Article $98 \S 1$ of the Code of Civil Procedure and the relevant provisions of the ordinance on lawyers' fees as the legal basis for this decision satisfies the aforementioned requirements resulting from Article $328 \S 2$ in relation to Article 361 of the Code of Civil Procedure, as it permits a determination why the Court of the second instance, in its own manner, ruled on the costs of the appeal proceedings. That justification enables an assessment of both the principle used for this decision by the Court of the second instance, and the amount of the sum awarded, in other words all elements that are necessary for an evaluation of this decision. Consequently, it permits the conclusion that the contested decision on costs of the appeal proceedings is correct as it is based on an appropriate factual and legal basis)."

${ }^{3}$ It should also be added that the Code de procédure civile, which was in use in the central Polish lands between 1808 and 1876, did not require decisions on costs to be justified, H. KRZYŻANOWSKI, Zasady postępowania cywilnego (Warszawa: nakładem autora, 1864), 291. My archival research conducted on the files of civil courts operating in Kalisz, Kraków, Bydgoszcz, Warszawa, and at the Court of the Peace in Śrem suggests that indeed the courts would not justify their decisions on costs as a rule or did so very briefly, Central Archive of Historical Records, archival fonds: Trybunat Cywilny Kaliski [The Civil Tribunal in Kalisz], State Archives in Bydgoszcz, fonds Trybunat Cywilny Departamentu Bydgoskiego w Bydgoszczy [The Civil Tribunal of the Bydgosz Department in Bydgoszcz], State Archives in Warszawa, fonds Akta Stanu Cywilnego Gmin Warszawskich [The Civil Registry Records of districts of Warsaw], State Archives in Poznań, fonds 53/4438/0 Sad Pokoju w Śremie [The Court of the Peace in Śrem].

${ }^{4}$ Code de procédure civile édition originale et seule officielle (Paris: Imprimerie Impériale, 1806). 
ordinances of the monarch and his governor regulating various specific matters were important.

Looking at the issue from a perspective with a certain level of generality, we can conclude that the components of expenses incurred in civil action were quite similar to ones we pay today. ${ }^{5}$ These included: court fees, attorneys' and experts' fees, travel expenses of the parties and other persons whose appearance was necessary, daily allowances for the parties themselves, witnesses ${ }^{6}$ and court ${ }^{7}$ officers, and costs of court correspondence (incurred by court officers ${ }^{8}$ ).

The trial costs were divided into court costs and extrajudicial costs. The former included court fees, while the latter included other expenses (costs of stamped paper used to prepare pleadings, fees for copies of judgements, costs of service, and attorneys' fees ${ }^{9}$ ).

Court fees were paid on an ongoing basis by the more urgent party (seeking to enter their case into the court register, applying for a copy of a judgement, etc. ${ }^{10}$ ). The plaintiff was usually the more urgent party, but it happened occasionally that the initiative was taken over by the defendant (e.g. main or incidental appeal). In accordance with Article 130 Code de procédure civile, the losing party was obliged to bear all the costs of the proceedings (including those incurred by the other party). It should be noted that the French Code of Civil Procedure, unlike the modern Polish Code of Civil Procedure (Article 98 para. 1), did not make reimbursement contingent on the claimant's application. ${ }^{11}$ However, the courts of the Duchy of Warsaw

\footnotetext{
${ }^{5}$ Compare Article 98 of the Act of 17 November 1964 - The Code of Civil Procedure and the Act of 28 July 2005 on court fees in civil proceedings, Journal of Laws of 2016, item 623, as amended.

${ }^{6}$ Witnesses rarely applied for reimbursement of travelling expenses or daily allowance, e.g. National Archives in Kraków, fonds Archiwum Wolnego Miasta Krakowa [Archives of the Free City of Kraków], court files, vol. trib. 17, sheet 4, vol. 49, sheet 485v; State Archives in Warszawa, fonds Akta Stanu Cywilnego Gmin Warszawskich [The Civil Registry Records of Warszawa] Boroughs, Precinct III, vol. 97, sheet 20v.

${ }^{7}$ Decree of 6 March 1811 on the payment of court costs by litigants and remuneration for experts and witnesses, Dziennik Praw, 3:236ff.

${ }^{8}$ Decree of 14 March 1809 on fees for burgraves (Dziennik Praw, 1:218ff.) and the Decree of 14 October 1811 on court officers and bailiffs (Dziennik Praw, 3:407ff.), especially Article 4.

${ }^{9} \mathrm{~W}$. NowAKOwSKI, Ustawa postępowania sądowego cywilnego z dnia 20 listopada 1864 roku ze zmianami zaprowadzonemi przez najwyżej zatwierdzone postanowienie z dnia 19 lutego $1875 \mathrm{r}$. i z objaśnieniami ułożonemi (Warszawa: Red. Biblioteki Umiejętności Prawnych, 1878-1879), part 1, p. 325, and part 2, p. 522.

${ }^{10}$ KRZYŻANOWSKI, Zasady postępowania, 221-22.

${ }^{11}$ J.A. Rogron, Kodeks postępowania cywilnego wytuszczony..., vol. 1 (Warszawa: Drukarnia Łątkiewicza przy ulicy Senatorskiej n. 467, 1829), 238-39. The provision in question was interpreted differently in H. KRZYŻANOwSKI, Zasady postępowania, 290.
} 
and Congress Poland, did not award any costs if no list of extrajudicial expenses (liquidation) was submitted. ${ }^{12}$

\section{STAMP DUTIES}

In the majority of trials, the court fees which were of great importance was the stamp fee associated with bringing action or the issuance of a copy of the sentence.

In the Duchy of Warsaw, and then in Congress Poland (until the unification of the judiciary), a total of three acts comprehensively regulating the principles of stamp duty collection were legislated. Chronologically, the earliest was the Sejm Act of March $24 .^{13}$ It was in force for only about three years. ${ }^{14}$ On June 1,1812 , it was replaced by another law passed by the Sejm on December 23, $1811 .^{15}$ The latter played the most important role among all the acts under discussion, as it was in force for more than half a century. In Congress Poland $\mathrm{it}^{16}$ was replaced by a law approved by the Sejm Act of 25 September (7 October) $1863 .{ }^{17}$ In the Free City of Kraków and its district, on September 16, 1833, the Assembly of Representatives on the initiative of the Senate passed its own stamp law, which entered into force on the day of its announcement, that is on October $15,1833 .^{18}$

\footnotetext{
${ }^{12}$ For example State Archives in Warszawa, fonds Akta Stanu Cywilnego Gmin Warszawskich [The Civil Registry Records of districts of Warsaw], Precinct II, vol. 99, sheet 326 (with the proviso na ten czas nie ustanawia [does not establish for this period]), Precinct II, vol. 99, sheet 361 (dla nie podanej likwidacji pomija [omits for an unspecified liquidation]), Central Archive of Historical Records, fonds Trybunat Cywilny Kaliski [The Civil Tribunal in Kalisz], vol. 322, sheet 799v (dla nie podanej likwidacji nie ustanawia [does not establish for an unspecified liquidation]).

${ }^{13}$ Dziennik Praw, 3:1ff. The act repealed earlier regulations on court fees (Article 42), but its solutions drew on Prussian patterns. (R. KowALCZYK, Polityka gospodarcza i finansowa Księstwa Warszawskiego w latach 1807-1812 (Łódź: Wydawnictwo Uniwersytetu Łódzkiego, 2010), 273.

${ }^{14}$ In principle, it entered into force on the day of publication (Article 41) and was derogated at the end of May 1812 ( $\S 1$ of the act of December 23, 1811).

${ }^{15}$ Dziennik Praw, 4:47ff.

${ }^{16}$ It was derogated four months after the announcement of the law approved by the decree of September 25 (October 7) 1863, that is on May 22 (June 3) 1864 (§ 1 of the Instruction indicating the procedure for collection and control of stamp duty [no place or date of publication]).

${ }^{17}$ Dziennik Praw, 61:216ff

${ }^{18}$ Article 80 of the Stamp Act of 16 September 1833, Dziennik Praw Rzeczypospolitey Krakowskiey 6345 D.G.S.
} 
The first act (dated 24 March 1809) very broadly circumscribed the subject of levying this tax. In the introduction to it we read that "all contracts, agreements, certificates, receipts, records, bonds, resolutions, in a word, anything written down in this regard is to be made on stamped paper." Stamped paper was to be used for all court correspondence and applications submitted to administrative authorities, bills of exchange (Article 15), sale contracts (Article 18) and wills (Article 37). Moreover, all salaried officials were obliged to buy stamped paper. ${ }^{19}$ Despite such a broad scope of taxation, revenues derived from stamped paper sales were not a substantial item in the budget. ${ }^{20}$

In court proceedings, the duty in question was applied in several ways. Firstly, in cases where the amount in controversy did not exceed 100 złoty, all letters were to be drawn up on stamped paper costing 0.8 złoty (Article 1). In cases with a higher amount in controversy and those concerning claims of an intangible nature, typically stamped paper of higher denomination was to be used (depending on the hierarchical position of the court competent to hear the case, Articles 2-6).

The Act of 24 March 1809 provided for two basic stamp fees: upon application [od wpisu] (paid at the beginning of the proceedings) and for a decree [od dekretu] (which was necessary to obtain a copy of the judgement). These fees were equal in every case. When the claimed amount was up to 10,000 złoty, the combined fees were about half a percent of it. In cases with a higher amount in controversy, the percentage of the fees was slightly lower. ${ }^{21}$

In cases concerning non-property claims, the amount of fees depended on the social and economic position of the claimant (Article 48): "If the Claimant belonged to a certain class, the class of peasants, or to the class of men whose property most likely did not exceed the amount of six thousand złoty, or if he was a soldier or a non-commissioned officer," then both charges were in total 2 złoty and 15 groszy, just like for a claim of 500 złoty. "If the Claimant belonged to the class of merchants-retailers, clerks, officers up to the rank of captain exclusively," then both fees totalled 50 złoty, just like for a claim of 10,000 złoty. Finally, "owners of real estate and large landed estates, merchants-wholesalers, bankers, factory entrepreneurs, higher officials, secular and military clergy, up to the rank of captain inclusively" were obliged to pay a total of 75 złoty, that is "as if the amount in controversy

\footnotetext{
${ }^{19}$ Dziennik Praw, vol. 3, table on p. 38.

${ }^{20}$ J. GodLEWSKI, Gtosy posta Maryampolskiego na Seymie roku 1811 w Warszawie miane (Warszawa: Druk. Rządowa, 1814), 25, 95.

${ }^{21}$ Dziennik Praw, vol. 3, table on p. 49ff.
} 
was 20,000 złoty." Furthermore, in any given case, the poor party was allowed to request an exemption from the fee (Article 65).

Widespread criticism of the act of March 24, 1809, which gave rise to many doubts as to its interpretation, resulted in the adoption of a new comprehensive act on stamp duty legislated by the next Sejm of the Duchy of Warsaw on December 23, 1811.22 The principles of assessment and collection of fees were changed radically. First of all, it should be noted that pursuant to the new law as many as six types of stamp paper went into circulation: ordinary, for accounts, for court expenses, for administrative matters, for cards and calendars, and for penalties. ${ }^{23}$

In civil cases, the paper for court expenses and ordinary paper were mainly used. The latter was used to pay a new type of fee which replaced the application fee and the one for a decree. It was called wpis główny, ${ }^{24}$ and its amount reflected the amounts of two fees in particular cases concerning property claims (for example, under the previous law the sum of two fees in a case concerning a claim of 10,000 złoty was 50 złoty, whereas according to the new law the fee was 80 złoty). Its amount, as well as the assessment of the fees it had replaced was conditional on the amount in controversy. As before, the law contained a table (albeit much simplified) on the basis of which the fee was determined. In the smallest-claim cases the fee could exceed 2 per cent of the claimed value, in the most serious cases it did not reach even 2 per mille.

In cases whose amount could not be expressed in money, the following rules were introduced. In land border cases, when the disputed area between neighbours was not larger than one wtóka chetmińska [Chełmno volok Translator's note $],{ }^{25}$ the application fee amounted to 600 złoty; when the disputed area was larger, the application fee was increased ( $\$ 10$ letter a). The entry in the property register was half as high as in the boundary cases $(\S 10$ letter b). In divorce proceedings, the fee depended largely on the court's discretion. The legislator merely stated that the fee will be "maximum 600 złoty in divorce cases, while lower fees are to be set by courts in proportion to the estate of the parties to divorce cases" ( $\$ 10$ letter d). According to Wincenty

\footnotetext{
${ }^{22}$ The provisions of this resolution were clarified by the Decree of 14 February 1812, Dziennik Praw, 4:181-87.

${ }^{23}$ KowalczyK, Polityka gospodarcza, 274.

${ }^{24} \mathrm{~W}$. TRZETRZEWIŃSKI, Zbiór praw i przepisów stemplowych $w$ czasie od dnia 23 grudnia 1811 roku do dnia 10 kwietnia 1828 wydanych (Warszawa: Drukarnia N. Glücksberga, 1828), 44.

${ }^{25}$ That is about 18 hectares - I. IHNATOWICZ and A. BIERNAT, Vademecum do badań nad historia XIX i XX wieku (Warszawa: Wydawnictwo Naukowe PWN, 2003), 44.
} 
Trzetrzewiński, this was the way to determine the fees in all cases in which object of the claim could not be expressed in monetary terms, concerning the civil status (recognition of a child, correction of the civil status record). ${ }^{26}$

In civil cases concerning "misdemeanours without financial consequences, the stamp fee will apply as if it were for a claim worth 5,000 złoty" ( $\$ 10$ letter c). Therefore, 40 złoty was due. According to Trzetrzewiński, this was a case of, among other things, disputes about easements and eviction. ${ }^{27}$

The wpis glówny fee was determined by the court in the first decision (that is usually after the first hearing) and if the sentence was interlocutory (przedstanowczy), the claimant was charged with it, and if it was final, the losing party was charged with it. ${ }^{28}$ Where the final judgement was preceded by interlocutory or preparatory judgements, an additional application fee was added for each of them $(\S 14)$.

Poor persons could be exempted from the stamp duty on the basis of a certificate issued by the "a local administrative authority, advised by the sub-prefect" ( $\$ 20$ letter o). The Government Commission of Revenue and Treasury in a rescript of July 4, 1822 specified that a person applying for such an exemption should submit an application to the local police authority (commune head, mayor, or precinct commissioner), which was to indicate the assets and reasons for which it was not possible to pay the application fee. The application was to be certified by two "landowners of a credible reputation" and a police authority. ${ }^{29}$

The Tsar's Decree of 25 September (October 7) 1863 maintained the division of application fees into main and additional ones (Article 62). The main application fee in cases concerning property claims worth up to 3,000 roubles was one percent of the amount in controversy; it was half a percent on the surplus in the range between 3,000 and 9,000 roubles, and on the surplus over 9000 roubles the fee was one and a half percent. ${ }^{30}$ Cases "with no pecuniary designation" were subject to a fee of 3 roubles. ${ }^{31}$ An additional fee each time was the tenth part of the main application fee (Article 68). This law also provided for the possibility of deferring the payment of the stamp duty on the grounds of poverty (Article 97). In order to obtain the exemp-

\footnotetext{
${ }^{26}$ TRZETRZEWIŃSKI, Zbiór praw i przepisów stemplowych, 44n4.

${ }^{27}$ Ibid., 44 and 43 n3.

${ }^{28}$ Ibid., 44 and p. 36 , footnote c.

${ }^{29}$ Ibid., 44 and $108 \mathrm{n} 16$.

${ }^{30}$ Item 148 of the Tariff of the stamp duty schedule attached to the schedule of September 25, (October 7), 1863.

${ }^{31}$ Ibid., item 149.
} 
tion, it was necessary to submit an application in accordance with the template no. 14 attached to the Instruction indicating the procedure for collection and control of stamp duties. The certificate did not require to be certified by the local authorities or citizens of a credible reputation, but the grant of a deferral was decided by the Court's fiscal control body ( $\$ 60$ of the Instruction). The interesting solution was to limit the number of simultaneous litigations in which a party could exercise the right of poor relief to three (Article 99).

\section{PRACTICE}

Our preliminary archival research shows that the provisions on costs of judicial proceedings were observed in practice. Interestingly, judgements concluding proceedings in particular instance quite often failed to adjudicate on extrajudicial expenses (probably due to the winning party failing to submit an appropriate application). For example, of the first 40 judgements that the second division of the Kalisz Tribunal issued in 1813, 24 were rulings on the substantive issue, which should necessarily include decisions on costs (and they actually did). In 21 cases, the amounts of application fees were indicated as well as the party to pay them. Only in six cases was the amount of the extrajudicial fees mentioned, which should be reimbursed to the winner by the losing party. ${ }^{32}$

In January and February 1810, a sub-judge of the Dispute Department of the Court of the Peace in Śrem heard 70 cases. In 31, decisions on extrajudicial expenses were made, appearing to be complete (in some cases, there were no sentences handed down or agreements were reached on specific amounts without specifying the share of the claims and the costs of litigation). In these 31 cases, extrajudicial fees amounted to 6.82 zloty on average. This gives an idea of the costs of serving pleadings or travel expenses of the parties and witnesses, but are not useful for estimation of lawyers' fees, as these rarely appeared before courts of the peace. ${ }^{33}$

Notwithstanding the above, it is doubtful whether the awarded extrajudicial costs fully compensated the successful party for the costs incurred. ${ }^{34}$

\footnotetext{
${ }^{32}$ Central Archives of Historical Records, fonds Trybunat Cywilny Kaliski, vol. 302.

${ }^{33}$ State Archives in Poznań, fonds 53/4438/0 Sąd Pokoju w Śremie, vol. 10.

${ }^{34}$ NowAKOWSKI, Ustawa postępowania sadowego, part 1, 325-26.
} 


\section{CONCLUSION}

The discussed regulations concerning court expenses are in principle similar to those used today while showing some characteristic differences. One of the most important obligations was the one to prepare all pleadings on stamped paper. The advantage of this solution was the reduction of the length of pleadings,${ }^{35}$ but the downside was an increased amount of time required to calculate the costs of the litigation. It is also interesting to note that fees in cases concerning non-property claims were contingent on the claimant's wealth. It should also be noted that nineteenth-century regulations, unlike today, ${ }^{36}$ provided for lower court fees in percentage terms in cases involving large claims in comparison with small claim cases. If we were to assume that the application fee is somehow equivalent, ${ }^{37}$ we would need to evaluate this solution as positive (after all, there is no simple correlation between the amount of the claim and the costs of maintaining the court building and court staff in connection with the handling of the case). And finally, the solution limiting the number of simultaneous litigations in which one party could exercise the right of poor relief to three should be seen as original as this prevented litigiousness.

\section{BIBLIOGRAPHY}

SOURCES OF LAW

Code de procédure civile édition originale et seule officielle [Code of Civil Procedure. Original and Official Edition]. Paris: Imprimerie Impériale, 1806.

Dekret z 14 marca 1809 r. w sprawie taksy dla burgrabiów [Decree of 14 March 1809 on fees for burgraves]. Dziennik Praw Księstwa Warszawskiego [Journal of Laws of the Duchy of Warsaw], 1:218-22.

Dekret z 6 marca 1811 r. w sprawie zapłaty kosztów sądowych przez strony procesowe oraz wynagrodzenia dla biegłych i świadków [Decree of 6 March 1811 on the payment of court costs by litigants and remuneration for experts and witnesses]. Dziennik Praw, 3:236-39.

\footnotetext{
${ }^{35}$ At any rate, their complexity was still criticised: Regulation on the manner of introducing cases by defenders and submitting edits to judgements, Zbiór przepisów administracyjnych Królestwa Polskiego. Wydziat Sprawiedliwości (Warszawa 1867), 8/2:107.

${ }^{36}$ Compare Article 13 para. 1 of the Act of 28 July 2005 on court fees in civil proceedings: "A proportional fee is charged in property cases; it amounts to $5 \%$ of the value of the object of dispute or appeal, but no less than 30 zloty and no more than 100,000 złoty."

${ }^{37}$ However, in literature it is considered not to be the case, compare KorZAN, Koszty postepowania cywilnego, 24.
} 
Dekret z 14 października 1811 r. w sprawie woźnych sądowych i komorników [Decree of 14 October 1811 on court officers and bailiffs]. Dziennik Praw, 3: 407-13.

Dekret z 14 lutego 1812 r. [Decree of 14 February 1812]. Dziennik Praw, 4: 181-87.

Instrukcja wskazująca sposób postępowania przy poborze i kontroli opłat stemplowych [Instruction indicating the procedure for collection and control of stamp duties]. No place or date of publication.

Rozporządzenie co do sposobu wprowadzania spraw przez obrońców i składania redakcji do wyroków [Ordinance on the manner of introducing cases by defenders and submitting edits for judgements]. In Zbiór przepisów administracyjnych Królestwa Polskiego. Wydział Sprawiedliwości, 8/2: 105-11. Warszawa 1867.

Ustawa z 24 marca 1809 r. [Decree of 24 March 1809]. Dziennik Praw, 3: 1-111.

Ustawa z 23 grudnia 1811 r. [Act of 23 December 1811]. Dziennik Praw, 4:47-110.

Ustawa z 16 września 1833 r. [Act of 6 September 1833]. Dziennik Praw Rzeczypospolitey Krakowskiey [Journal of Laws of the Republic of Kraków], 6345 D.G.S.

Ustawa o opłatach stemplowych z 25 września (7 października) 1863 [Act of 25 September (7 October) 1863 on stamp fees]. Dziennik Praw Królestwa Polskiego [Journal of Laws of the Kingdom of Poland], 61:220-355.

Ustawa z 17 listopada 1964 r. - Kodeks postępowania cywilnego [Act of 17 November 1964The Code of Civil Procedure], Journal of Laws of 2016, item 1822, as amended.

Ustawa z 28 lipca 2005 r. o kosztach sądowych w sprawach cywilnych [Act of 28 July 2005 on court fees in civil proceedings], Journal of Laws of 2016, item 623 as amended.

\section{ARCHIVAL SOURCES}

Central Archive of Historical Records, fonds Trybunat Cywilny Kaliski [The Civil Tribunal in Kalisz].

National Archives in Kraków, fonds Archiwum Wolnego Miasta Krakowa [The Archives of the Free City of Kraków].

National Archives in Poznań, fonds Są Pokoju w Śremie [The Court of the Peace in Śrem].

State Archives in Warszawa, fonds Akta Stanu Cywilnego Gmin Warszawskich [The Civil Registry Records of districts of Warsaw].

\section{CASE LAW}

Postanowienie Sądu Najwyższego z dnia 10 października 2013 r. [Decision of the Supreme Court of 10 October 2013], file ref. no. III CKN 30/13, LEX no. 877707.

\section{LITERATURE}

Bukowski, Tadeusz. Rozstrzyganie o kosztach procesu cywilnego. Warszawa: Wydawnictwo Prawnicze, 1971.

Godlewski, Józef. Gtosy posta Maryampolskiego na Seymie roku 1811 w Warszawie miane. Warszawa: Druk. Rządowa, 1814.

IhNATOwICZ, Ireneusz, and Andrzej BIERNAT. Vademecum do badań nad historia XIX i XX wieku. Warszawa: Wydawnictwo Naukowe PWN, 2003. 
Kodeks postępowania cywilnego. Komentarz. Edited by Andrzej Zieliński. Warszawa: Wydawnictwo C.H. Beck, 2017.

Kodeks postępowania cywilnego. Komentarz. Edited by Andrzej Marciniak and Kazimierz Piasecki. Vol. 1. Warszawa: Wydawnictwo C.H. Beck, 2016.

KoRZAN, Kazimierz. Koszty postępowania cywilnego a naktady państwa na utrzymanie wymiaru sprawiedliwości. Gdańsk: Wydawnictwo Prawnicze i Ekonomiczne "Lex," 1992.

KowAlCZyK, Rafał. Polityka gospodarcza i finansowa Księstwa Warszawskiego w latach 18071812. Łódź: Wydawnictwo Uniwersytetu Łódzkiego, 2010.

KRZYŻANOWSKI, Hieronim. Zasady posteppowania cywilnego. Warszawa: nakładem autora, 1864.

NowaKowsKI, Władysław. Ustawa postepowania sąowego cywilnego z dnia 20 listopada 1864 roku ze zmianami zaprowadzonemi przez najwyżej zatwierdzone postanowienie z dnia 19 lutego 1875 r. i z objaśnieniami ułożonem, cz. 1 i 2. Warszawa: Red. Biblioteki Umiejętności Prawnych, 1878-1879.

RogRON, Joseph A. Kodeks posteppowania cywilnego wytuszczony.... Translated and edited by Damazy Dzierożyński. Warszawa: Drukarnia Łątkiewicza przy ulicy Senatorskiej n. 467, 1829.

TRZETRZEWIŃSKI, Wojciech. Zbiór praw i przepisów stemplowych w czasie od dnia 23 grudnia 1811 roku do dnia 10 kwietnia 1828 wydanych. Warszawa: Drukarnia N. Glücksberga, 1828.

\section{FEES PAID IN CIVIL CASES IN THE DUCHY OF WARSAW AND THE KINGDOM OF POLAND (UNTIL 1876)}

\section{Summary}

The article concerns costs borne by parties to court cases in the Duchy of Warsaw and the Kingdom of Poland (until the unification of the Polish judiciary with the Russian system in the 1870s). Litigation costs included: court fees, attorneys' and experts' fees, travel expenses incurred by the parties and other persons whose appearance was necessary, daily allowances for the parties, witnesses and court officers, and costs of correspondence (delivered by court officers). The most important costs were the court fees, which were paid using stamped paper. The author focused on the content of three acts which comprehensively regulated the collection of stamp duty (acts of 1809, 1811 and 1863). In property litigations, the amount of stamp duty depended on the value of the disputed subject matter, while it had a regressive character (the bigger the claim, the lower the fees). However, in cases concerning non-financial claims, the fee depended on the affluence of the parties or was set as a lump sum.

Keywords: civil action costs; fees; Congress Poland.

Translated by Tomasz Patkowski

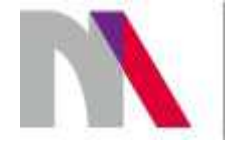

The preparation of the English version of Roczniki Nauk Prawnych (Annals of Iuridical Sciences) and its publication in electronic databases was financed under contract no. $836 / \mathrm{P}$ DUN/2018 from the resources of the Minister of Science and Higher Education for the popularization of science. 